Publisher: GSA

Journal: GEOL: Geology

DOI:10.1130/G38985.1

\title{
1 Tropical weathering of the Taconic orogeny as a driver for
}

\section{Ordovician cooling}

3 Nicholas L. Swanson-Hysell ${ }^{1}$ and Francis A. Macdonald ${ }^{2}$

$4{ }^{1}$ Department of Earth and Planetary Science, University of California, Berkeley,

5 California 94720-4767, USA

$6{ }^{2}$ Department of Earth and Planetary Sciences, Harvard University, Cambridge,

7 Massachusetts 02138, USA

8 ABSTRACT

9 The Earth's climate cooled through the Ordovician Period leading up to the

10 Hirnantian glaciation. Increased weatherability of silicate rocks associated with

11 topography generated on the Appalachian margin during the Taconic orogeny has been

12 proposed as a mechanism for Ordovician cooling. However, paleogeographic

13 reconstructions typically place the Appalachian margin within the arid subtropics, outside

14 of the warm and wet tropics where chemical weathering rates are highest. In this study

15 we reanalyze the paleomagnetic database and conclude that Ordovician constraints from

16 cratonic Laurentia are not robust. Instead, we use paleomagnetic data from well-dated

17 volcanic rocks in the accreting terranes to constrain Laurentia's position given that the

18 Appalachian margin was at, or equatorward of, the paleolatitude of these terranes. To

19 satisfy these allochthonous data, Laurentia must have moved toward the equator during

20 the Ordovician such that the Appalachian margin was within $10^{\circ}$ of the equator by 465

21 Ma. This movement into the tropics coincided with the collision and exhumation of the

22 Taconic arc system, recorded by a shift in neodymium isotope data from shale on the 
Publisher: GSA

Journal: GEOL: Geology

DOI: $10.1130 / \mathrm{G} 38985.1$

23 Appalachian margin to more juvenile values. This inflection in detrital neodymium

24 isotope values precedes a major downturn in global seawater strontium isotopic values by

25 more than one million years, as would be predicted from a change in weathering input

26 and the relatively long residence time of strontium in the ocean. These data are consistent

27 with an increase in global weatherability associated with the tropical weathering of mafic

28 and ultramafic lithologies exhumed during the Taconic arc-continent collision. A Taconic

29 related increase in weatherability is a viable mechanism for lowering atmospheric $\mathrm{CO}_{2}$

30 levels through silicate weathering contributing to long-term Ordovician cooling.

\section{INTRODUCTION}

32 Ordovician strata record the transition from an Early Ordovician ice-free world to

33 end-Ordovician glaciation and mass extinction (Cooper and Sadler, 2012). Several

34 hypotheses have been proposed to account for this cooling and the initiation of glaciation

35 including: increased carbon burial (Brenchley et al., 1994), aerosol release from

36 volcanism (Buggisch et al., 2010), decreased volcanic outgassing (McKenzie et al.,

37 2014), increased silicate weathering due to topography associated with the Taconic

38 orogeny (Kump et al., 1999), and increased weathering of fresh volcanic rocks (Young et

39 al., 2009). Oxygen isotope data from brachiopods and conodonts indicate that Hirnantian

40 glaciation is the culmination of longer term cooling from 480 to $445 \mathrm{Ma}$ (Trotter et al.,

41 2008; Veizer and Prokoph, 2015). Although short-term perturbations such as increased

42 organic carbon burial inferred from positive carbon isotope excursions, changes in ocean

43 circulation, or sulfur aerosol release could account for transient cooling associated with

44 the Hirnantian glacial maximum, tectonic changes associated with long-term changes to

$45 \mathrm{CO}_{2}$ sources or sinks are required to drive $\sim 35 \mathrm{~m}$.y. of cooling. An increase in 
Publisher: GSA

Journal: GEOL: Geology

DOI:10.1130/G38985.1

46 global weatherability can lead to $\mathrm{CO}_{2}$ levels decreasing through increased silicate

47 weathering, associated delivery of alkalinity to the ocean, and sequestration of

48 bicarbonate in chemical sediments. The silicate weathering feedback can lead to

49 stabilization at a lower steady-state $\mathrm{CO}_{2}$ level (Kump et al., 1999).

50 Arc-continent collision is a tectonic process that can combine the mechanisms for

51 cooling outlined here and lead to a decrease in volcanic outgassing through the death of

52 an arc, and an increase in silicate weathering through increased topography and the

53 exhumation of highly weatherable mafic and ultramafic rocks (Reusch and Maasch,

54 1998; Jagoutz et al., 2016). Arc-continent collision associated with the Taconic orogeny

55 has been suggested to be associated with Ordovician cooling (Reusch and Maasch, 1998),

56 but paleogeographic reconstructions typically place the Taconic arc system outside of the

57 tropic weathering belt and within the arid subtropics (e.g., Mac Niocaill et al., 1997;

58 Domeier, 2016; Torsvik and Cocks, 2017). Modern evaporite belts and the paleolatitude

59 of evaporites constrain the arid subtropics to be persistently between latitudes of $15^{\circ}$ and $35^{\circ}$

60 (Evans, 2006). Given that weathering rates are strongly dependent on temperature and

61 precipitation, and that weathering rates within basaltic watersheds in the tropics are

62 approximately an order of magnitude higher than those in mid-latitudes (Dessert et al.,

63 2003), such a subtropical position would likely preclude major $\mathrm{CO}_{2}$ drawdown associated

64 with arc-continent collision (Jagoutz et al., 2016). Consequently, the reconstruction of the

65 paleolatitude of the orogeny is critical to the hypothesis that an increase in silicate

66 weatherability associated with the Taconic orogeny drove a portion of Ordovician

67 cooling. Did the Taconic arc-continent collision occur in the arid subtropics or in the wet

68 tropics? 
Publisher: GSA

Journal: GEOL: Geology

DOI:10.1130/G38985.1

TECTONICS OF THE TACONIC OROGENY

70 The Taconic orogeny encompasses Ordovician collisional and accretionary events

71 between volcanic arcs that formed within the Iapetus Ocean and the Appalachian margin

72 of Laurentia. The Taconic orogeny has been separated into three broad phases (van Staal

73 and Barr, 2012): Taconic 1 (495-488 Ma) includes local amphibolite-grade

74 metamorphism in the arc terranes; Taconic 2 (488-461 Ma) spans the collision of the

75 leading edge of the Taconic arc system with distended fragments and promontories of the

76 Laurentian margin and the initiation of north-directed subduction (Fig. 1); and Taconic 3

77 (461-445 Ma) comprises later arc accretion events. By ca. $465 \mathrm{Ma}$, amalgamated arc

78 terranes and fragments of the margin were thrust onto Laurentia, and delivered arc

79 detritus, including detrital chromite, into marginal basins (e.g., Hiscott, 1978; Macdonald

80 et al., 2017).

81

82 The colliding Taconic arc system extended west (paleocoordinates in Fig. 1) into

83 the southern Appalachians as far as Alabama (Hibbard, 2000), and east along the

84 Greenland margin to Ellesmere Island (Trettin, 1987). This elongate east-west exposure

85 of the arc system was all within a similar latitude band (Fig. 1).

\section{PALEOGEOGRAPHY}

87 Concerted efforts over decades of integrating geologic and paleomagnetic data

88 have led to an understanding that from the Cambrian into the Ordovician, Laurentia's

89 Appalachian margin was oriented east-west as the northern boundary of the Iapetus

90 Ocean (Mac Niocaill et al., 1997). Although paleogeographic models typically place this

91 margin south of $20^{\circ} \mathrm{S}$ in the relatively arid subtropics, this position in the Ordovician is 
Publisher: GSA

Journal: GEOL: Geology

DOI:10.1130/G38985.1

92 poorly constrained due to a lack of reliable paleomagnetic poles from cratonic Laurentia.

93 In the comprehensive apparent polar wander path compilation of Torsvik et al. (2012),

94 only two poles are included for the Ordovician: the St. George Group

95 and Table Head Group limestones of

96 Newfoundland. However, the Table Head Group limestones fail a conglomerate test

97 (Hodych, 1989). Therefore, their remanence, and the similar remanence of the underlying

98 St. George Group, must be the result of remagnetization. The Table Head Group rocks

99 pass a fold test, indicating that remagnetization occurred prior to Devonian folding.

100 Exclusion of these poles exacerbates an already large temporal gap between Laurentia

101 poles in the Torsvik et al. (2012) compilation, such that there are no robust poles from the

102 craton between the ca. 490 Ma Oneota Dolomite and the ca. 438 Ma Ringgold Gap poles

103 (Fig. 2). The paleolatitudes implied by Cambrian and Silurian poles for Laurentia's distal

104 margin (e.g., the New York and St. Lawrence promontories) are both in the subtropics

105 (Fig. 2), and extrapolation between these poles (such as a spline fit; Torsvik et al., 2012)

106 keeps Laurentia at a similar position through the Ordovician.

107 Given that there are no robust Ordovician paleomagnetic data from the Laurentian

108 craton, we take the approach of using paleomagnetic data from well-dated volcanic rocks

109 on the accreting terranes with magnetizations that are interpreted to be primary. Because

110 the Appalachian margin must have been at or equatorward of these terranes, these data

111 provide the best existing constraints on the Ordovician paleolatitude of Laurentia and

112 have been interpreted to indicate the presence of peri-Laurentian, intra-Iapetan, and peri-

113 Avalonian arc volcanism (Mac Niocaill et al., 1997). Open source reconstructions

114 developed in GPlates software (https://www.gplates.org/) for the 
Publisher: GSA

Journal: GEOL: Geology

DOI:10.1130/G38985.1

115 evolution of the Iapetus Ocean (Domeier, 2016; Torsvik and Cocks, 2017) provide an

116 excellent framework that can be modified with this approach.

117 In contrast to the Laurentian craton, eight robust Ordovician paleomagnetic data

118 sets have been reported from accreted Taconic arc terranes through extensive efforts of

119 the Rob Van der Voo research group at the University of

120

121 Michigan (USA) (see the GSA Data Repository ${ }^{1}$ ). The interpretation of primary

122 remanence in these volcanic rocks is variably based on dual polarities, positive fold tests,

123 and interpretation of magnetic mineralogy. The oldest such locality is within the Notre

124 Dame arc of Newfoundland, where ca. 477 Ma mafic volcanics of the Moreton's Harbour

125 Group yielded a paleolatitude of $\sim 11^{\circ} \mathrm{S}$

$126\left(8^{\circ}-15^{\circ} \mathrm{S}\right.$ at $95 \%$ confidence $)$ and were therefore interpreted to have formed in close

127 proximity to Laurentia (Johnson et al., 1991). Four paleomagnetic localities from ca.

128 470-465 Ma volcanic rocks of the Victoria arc of Newfoundland provide paleolatitude

129 constraints; the lowest latitude results are from the Lawrence Head volcanics,

130 which were at $\sim 12^{\circ} \mathrm{S}\left(2^{\circ}-24^{\circ} \mathrm{S}\right.$ at $95 \%$ confidence) (see

131 the Data Repository). Similar aged pillow lavas from arc terranes in Newfoundland (the

132 Annieopsquotch arcs in Fig. 2) give paleolatitudes of $\sim 30^{\circ} \mathrm{S}$ that have been interpreted to

133 indicate that they formed some distance from the margin within the Iapetus Ocean (Van

134 der Voo et al., 1991). In New England (northeastern United States), ca. 467 Ma volcanics

135 of the Bronson Hill arc yield a paleolatitude of $\sim 20^{\circ} \mathrm{S}\left(12^{\circ}-29^{\circ} \mathrm{S}\right.$ at $95 \%$ confidence $)$

136 while younger ca. $458 \mathrm{Ma}$ volcanics give paleolatitudes of $\sim 14^{\circ} \mathrm{S}\left(8^{\circ}-23^{\circ} \mathrm{S}\right.$ at $95 \%$

137 confidence) and $\sim 11^{\circ} \mathrm{S}\left(6^{\circ}-16^{\circ} \mathrm{S}\right.$ at $95 \%$ confidence $)$. 
Publisher: GSA

Journal: GEOL: Geology

DOI:10.1130/G38985.1

138 Although the Notre Dame arc was at a low latitude by ca. $475 \mathrm{Ma}$ (Johnson et al.,

139 1991) when it collided with hyperextended fragments of the Laurentian margin

140 (Macdonald et al., 2014; van Staal and Barr, 2012), the Taconic seaway separated these

141 terranes from the Laurentian autochthon until they were exhumed ca. $465 \mathrm{Ma}$. While the

142 width of the Taconic seaway is unconstrained, the hyperextended margin of northeast

143 Australia, which extends $>500 \mathrm{~km}$ from the craton, may be a modern analog. This $\sim 500-$

144 km-wide seaway closed between 475 and 465 Ma.

145 Paleolatitude constraints from ca. 470-465 Ma volcanics of the Taconic arc

146 terranes span $\sim 20^{\circ}$ of latitude, suggesting a distended arc system comparable to the

147 modern southwest Pacific arc system (Fig. 1; Mac Niocaill et al., 1997). Although the

148 precise latitudinal spread is difficult to resolve given uncertainty associated with

149 paleolatitude estimates, we interpret the spread of these latitudes to represent the leading

150 and trailing edges of the arc system (Fig. 1). This approach is a simplification; analogous

151 to the modern southwest Pacific, there were probably other active subduction zones.

152 Shortening during the Taconic and subsequent orogenies would have translated these

153 terranes inward toward the craton, further contributing to the interpretation that Laurentia

154 was equatorward of their paleolatitudes. Overall, the paleomagnetic database strongly

155 supports a revised reconstruction wherein the Appalachian Laurentian margin was

156 equatorward of $10^{\circ} \mathrm{S}$ at $465 \mathrm{Ma}$ (Fig. 1).

\section{WEATHERING PROXY DATA}

158 Strontium and neodymium isotope data were compiled and recalculated (see the

159 Data Repository) using The Geological Time Scale 2012 (see Cooper and Sadler, 2012). 
Publisher: GSA

Journal: GEOL: Geology

DOI:10.1130/G38985.1

$161 \quad{ }^{87} \mathrm{Sr} /{ }^{86} \mathrm{Sr}$ data developed from the conodont apatite record a broad

162 decline from 0.7090 to 0.7088 between 480 and $465 \mathrm{Ma}$. This gradual decline is followed

163 by a sharp deflection at $465 \mathrm{Ma}$ toward more juvenile ${ }^{87} \mathrm{Sr} /{ }^{86} \mathrm{Sr}$ values, reaching 0.7079

164 by $450 \mathrm{Ma}$ (Saltzman et al., 2014; Fig. 2). Neodymium isotope $\left(\varepsilon_{\mathrm{Nd}}\right)$ data from fine-

165 grained siliciclastic rocks deposited on the distal margin of Laurentia, on the Taconic

166 allochthon, and Sevier basin (Gleason et al., 2002; Macdonald et al., 2017) display an

167 inflection to more positive values at $465 \mathrm{Ma}$ consistent with a substantial increase of

168 sediment being weathered from juvenile lithologies (Fig. 2). This inflection in $\varepsilon_{\mathrm{Nd}}$ values

169 occurs later in more interior basins (Fig. 2) that did not receive arc-derived sediment until

170 subsequent accretionary events thrust arc rocks onto Laurentia between ca. 455 and 450

171 Ma (Macdonald et al., 2014, 2017).

172 DISCUSSION

173 The paleogeographic reconstruction presented here suggests that the Appalachian

174 margin was at a significantly lower latitude than is typically depicted, equatorward of

$17510^{\circ} \mathrm{S}$ by $465 \mathrm{Ma}$ (Fig. 1). Our reconstruction is compatible with paleomagnetic data from

176 the Taconic arc system and is not in conflict with robust paleomagnetic poles from

177 Laurentia.

178 We propose that the broad rise in oxygen isotope values and decline in strontium

179 isotope values between 490 and $465 \mathrm{Ma}$ (Fig. 2) are related to the movement of the

180 Taconic arc system into the tropics and collision of the leading edge with distended

181 fragments and promontories of the Laurentian margin (Taconic orogenic phase 2 of van

182 Staal and Barr, 2012). A concomitant increase in global weatherability would have

183 caused cooling through $\mathrm{CO}_{2}$ drawdown, moderated by the silicate weathering feedback. 
Publisher: GSA

Journal: GEOL: Geology

DOI:10.1130/G38985.1

184 In addition, we argue that the sharp drop in ${ }^{87} \mathrm{Sr} /{ }^{86} \mathrm{Sr}$ values, the shift toward more

185 juvenile $\varepsilon \mathrm{Nd}$ values in shale from the distal margin of Laurentia, and the additional

186 increase in oxygen isotope values between 465 and $455 \mathrm{Ma}$ (Fig. 2) are due to the uplift

187 and exhumation of the Taconic arc system in the tropics (peak of Taconic 2) followed by

188 continued Late Ordovician arc accretion (Taconic 3). This exhumation led to uplift and

189 erosion of island arc volcanics and suprasubduction ophiolites, as evidenced by the

190 presence of detrital chromite in Middle to Late Ordovician foreland basins (e.g., Hiscott, 191 1978).

192 Increased weathering of volcanic arcs associated with the Taconic orogeny was

193 previously invoked to explain the Ordovician drop in ${ }^{87} \mathrm{Sr} /{ }^{86} \mathrm{Sr}$ values (Young et al.,

194 2009). The feasibility of this scenario was supported with a model in which global

195 weatherability was increased by $25 \%$ and a new flux of riverine ${ }^{87} \mathrm{Sr} /{ }^{86} \mathrm{Sr}$ was introduced

196 from weathering basalt with a composition of 0.7043 (Young et al., 2009). The $\varepsilon_{\mathrm{Nd}}$

197 compilation from the Appalachian margin of Laurentia, which records local provenance,

198 is consistent with the hypothesis that the Taconic orogeny played a significant role in the

199 inferred increase in global weatherability and riverine ${ }^{87} \mathrm{Sr} /{ }^{86} \mathrm{Sr}$ input to the ocean. The

200 inflection in $\varepsilon_{\mathrm{Nd}}$ data from distal margin basins occurs a few million years prior to the

201 inflection in the global ${ }^{87} \mathrm{Sr} /{ }^{86} \mathrm{Sr}$ curve (Fig. 2). This lead time is predicted if the

202 weathering of Taconic terranes is a significant driver of the global strontium signal.

203 Juvenile $\varepsilon_{\mathrm{Nd}}$ values should be imparted in siliciclastic rocks over the time scale that

204 sediment transits from source to sink (thousand year time scales), whereas strontium has

205 a multimillion year residence time in the ocean such that a prolonged interval of arc

206 weathering would be necessary to significantly change seawater ${ }^{87} \mathrm{Sr} /{ }^{86} \mathrm{Sr}$. A complication 
Publisher: GSA

Journal: GEOL: Geology

DOI:10.1130/G38985.1

207 in this interpretation is that the age model for the $\varepsilon_{\mathrm{Nd}}$ data is anchored by $\mathrm{U}-\mathrm{Pb}$ zircon

208 ages from ashes within the same stratigraphic sections (Macdonald et al., 2017), whereas

209 the ${ }^{87} \mathrm{Sr} /{ }^{86} \mathrm{Sr}$ age model is based on Cooper and Sadler (2012; Saltzman et al., 2014), so

210 the estimated temporal offset is as accurate as the calibration of the geological time scale.

211 Although other arc systems likely enhanced global weatherability in the

212 Ordovician, such as those in the paleo-Asian Ocean and the Fammetanian

213 arc of present-day Argentina, the Taconic arcs likely played an

214 outsized role as they were exhumed along an east-west belt in the tropics during the

215 closure of the Iapetus Ocean (Fig. 1). Exhumation would have created significant

216 topography composed of mafic and ultramafic lithologies through a wide swath across

217 the tropics. This scenario has similarities to the low-latitude closure of the Neo-Tethys

218 Ocean, and two-phase collision of the trans-Tethyan subduction system, which coincided

219 with the two-pronged cooling trend from the Cretaceous to Oligocene (Jagoutz et al.,

220 2016). The closure of major oceanic basins along east-west belts in the tropics may have

221 been a significant driver of long-term cooling trends throughout Earth history. Following

222 the Taconic orogeny, the Appalachian margin moved away from the tropics, so that

223 collisions associated with the Salinic orogeny in the Silurian would have occurred at

$224 \sim 20^{\circ} \mathrm{S}$, where there would have been a lesser effect on global weatherability (Fig. 2).

225 Lower $p \mathrm{CO}_{2}$ resulting from elevated global weatherability could have set the

226 stage for the growth of ice sheets during the Hirnantian. However, these tectonic

227 boundary conditions may not be the sole driver for the Hirnantian ice advance, and other

228 factors such as orbital forcing, changing ocean circulation, organic carbon burial, or rapid 
Publisher: GSA

Journal: GEOL: Geology

DOI: $10.1130 / \mathrm{G} 38985.1$

229 changes in albedo may have caused the shorter term cooling associated with the

230 Hirnantian glacial maximum.

\section{CONCLUSIONS}

232 Our paleogeographic reconstruction constrained by the paleolatitude of

233 allochthonous volcanic rocks demonstrates that Laurentia moved toward the equator

234 during the Ordovician such that the Appalachian margin was equatorward of $10^{\circ} \mathrm{S}$ at 465

235 Ma. This movement into the tropics coincided with (1) collision and exhumation of the

236 Taconic arc system marked by the appearance of detrital chromite in foreland basins; (2)

237 a shift in $\varepsilon_{\mathrm{Nd}}$ data from fine-grained siliciclastic rocks on the Laurentian margin to more

238 juvenile values; (3) a drop in seawater ${ }^{87} \mathrm{Sr} /{ }^{86} \mathrm{Sr}$ values to more juvenile values; and (4) a

239 continued trend to higher values in the oxygen isotopic composition of both brachiopod

240 carbonate and conodont phosphate. These data are consistent with tropical weathering of

241 the Taconic arc-continent collision as a driver of Ordovician cooling.

\section{REFERENCES CITED}

243 Brenchley, P.J., Marshall, J.D., Carden, G.A.F., Robertson, D.B.R., Long, D.G.F.,

244 Meidla, T., Hints, L., and Anderson, T.F., 1994, Bathymetric and isotopic evidence

245 for a short-lived Late Ordovician glaciation in a greenhouse period: Geology, v. 22,

246 p. 295-298, doi:10.1130/0091-7613(1994)022<0295:BAIEFA>2.3.CO;2.

247 Buggisch, W., Joachimski, M.M., Lehnert, O., Bergström, S.M., Repetski, J.E., and

248 Webers, G.F., 2010, Did intense volcanism trigger the first Late Ordovician

249 icehouse?: Geology, v. 38, p. 327-330, doi:10.1130/G30577.1.

250 Cooper, R., and Sadler, P., 2012, The Ordovician Period, in Gradstein, F.M., et al., The

251 geologic time scale 2012: Boston, Elsevier, v. 2, p. 489-524. 
Publisher: GSA

Journal: GEOL: Geology

DOI:10.1130/G38985.1

252 Dessert, C., Dupré, B., Gaillardet, J., François, L.M., and Allègre, C.J., 2003, Basalt

253 weathering laws and the impact of basalt weathering on the global carbon cycle:

254 Chemical Geology, v. 202, p. 257-273, doi:10.1016/j.chemgeo.2002.10.001.

255 Domeier, M., 2016, A plate tectonic scenario for the Iapetus and Rheic oceans:

256 Gondwana Research, v. 36, p. 275-295, doi:10.1016/j.gr.2015.08.003.

257 Evans, D.A.D., 2006, Proterozoic low orbital obliquity and axial-dipolar geomagnetic

258 field from evaporite palaeolatitudes: Nature, v. 444 , p. 51-55,

259 doi:10.1038/nature05203.

260 Gleason, J.D., Finney, S.C., and Gehrels, G.E., 2002, Paleotectonic implications of a

261 mid- to late-Ordovician provenance shift, as recorded in sedimentary strata of the

262 Ouachita and southern Appalachian mountains: Journal of Geology, v. 110, p. 291-

$263 \quad 304$, doi:10.1086/339533.

264 Hibbard, J., 2000, Docking Carolina: Mid-Paleozoic accretion in the southern

265 Appalachians: Geology, v. 28, p. 127-130, doi:10.1130/0091-

$2667613(2000) 28<127:$ DCMAIT $>2.0 . C O ; 2$.

267 Hiscott, R.N., 1978, Provenance of Ordovician deep-water sandstones, Tourelle

268 Formation, Quebec, and implications for initiation of the Taconic orogeny: Canadian

269 Journal of Earth Sciences, v. 15, p. 1579-1597, doi:10.1139/e78-163.

270 Hodych, J.P., 1989, Limestones of western Newfoundland that magnetized before

271 Devonian folding but after Middle Ordovician lithification: Geophysical Research

272 Letters, v. 16, p. 93-96, doi:10.1029/GL016i001p00093. 
Publisher: GSA

Journal: GEOL: Geology

DOI:10.1130/G38985.1

273 Jagoutz, O., Macdonald, F.A., and Royden, L., 2016, Low-latitude arc-continent collision

274 as a driver for global cooling: Proceedings of the National Academy of Sciences of

275 the United States of America, v. 113, p. 4935-4940, doi:10.1073/pnas.1523667113.

279 Johnson, R.J., van der Pluijm, B.A., and Van der Voo, R., 1991, Paleomagnetism of the

280 Moreton's Harbour Group, northeastern Newfoundland Appalachians: Evidence for

281 an Early Ordovician island arc near the Laurentian margin of Iapetus: Journal of

282 Geophysical Research, v. 96, p. 11,689-11,701, doi:10.1029/91JB00870.

283 Kump, L.R., Arthur, M., Patzkowsky, M.E., Gibbs, M.E., Pinkus, M.T., and Sheehan,

284 P.M., 1999, A weathering hypothesis for glaciation at high atmospheric $p \mathrm{CO}_{2}$ during

285 the Late Ordovician: Palaeogeography, Palaeoclimatology, Palaeoecology, v. 152,

286 p. 173-187, doi:10.1016/S0031-0182(99)00046-2.

287 Macdonald, F.A., Ryan-Davis, J., Coish, R.A., Crowley, J.L., and Karabinos, P., 2014, A

288 newly identified Gondwanan terrane in the northern Appalachian Mountains:

289 Implications for the Taconic orogeny and closure of the Iapetus Ocean: Geology,

$290 \quad$ v. 42, p. 539-542, doi:10.1130/G35659.1.

291 Macdonald, F.A., Karabinos, P., Crowley, J.L., Hodgin, E.B., Crockford, P.W., and

292 Delano, J.W., 2017, Bridging the gap between the foreland and the hinterland, II:

293 Geochronology and tectonic setting of Ordovician magmatism and basin formation

294 on the Laurentian margin of New England and Newfoundland: American Journal

295 of Science. 
Publisher: GSA

Journal: GEOL: Geology

DOI:10.1130/G38985.1

299 Mac Niocaill, C., van der Pluijm, B.A., and Van der Voo, R., 1997, Ordovician

300 paleogeography and the evolution of the Iapetus ocean: Geology, v. 25, p. 159-162, doi:10.1130/0091-7613(1997)025<0159:OPATEO>2.3.CO;2.

302 McKenzie, N.R., Hughes, N.C., Gill, B.C., and Myrow, P.M., 2014, Plate tectonic

303 influences on Neoproterozoic-early Paleozoic climate and animal evolution:

304 Geology, v. 42, p. 127-130, doi:10.1130/G34962.1.

305 Prokoph, A., Shields, G.A., and Veizer, J., 2008, Compilation and time-series analysis of a marine carbonate $\delta^{18} \mathrm{O}, \delta^{13} \mathrm{C},{ }^{87} \mathrm{Sr}{ }^{86} \mathrm{Sr}$ and $\delta^{34} \mathrm{~S}$ database through

309 Reusch, D.N., and Maasch, K.A., 1998, The transition from arc volcanism to exhumation, 310 weathering of young $\mathrm{Ca}, \mathrm{Mg}$, Sr silicates, and $\mathrm{CO}_{2}$ drawdown, in Crowley, T.J., and

311 Burke, K.C., eds., Tectonic boundary conditions for climate reconstructions: Oxford 312 Monographs on Geology and Geophysics no. 39, p. 261-276.

313 Saltzman, M.R., Edwards, C.T., Leslie, S.A., Dwyer, G.S., Bauer, J.A., Repetski, J.E., 314 Harris, A.G., and Bergström, S.M., 2014, Calibration of a conodont apatite-based 315 Ordovician ${ }^{87} \mathrm{Sr}{ }^{86} \mathrm{Sr}$ curve to biostratigraphy and geochronology: Implications for 316 stratigraphic resolution: Geological Society of America Bulletin, v. 126, p. 1551$317 \quad$ 1568, doi:10.1130/B31038.1. 
Publisher: GSA

Journal: GEOL: Geology

DOI:10.1130/G38985.1

318 Torsvik, T.H., and Cocks, L.R.M., 2017, Earth history and palaeogeography: Cambridge,

$319 \quad$ UK, Cambridge University Press, 311 p., doi:10.1017/9781316225523.

320 Torsvik, T.H., Van der Voo, R., Preeden, U., Mac Niocaill, C., Steinberger, B.,

321 Doubrovine, P.V., van Hinsbergen, D.J., Domeier, M., Gaina, C., and Tohver, E.,

322 2012, Phanerozoic polar wander, palaeogeography and dynamics: Earth-Science

323 Reviews, v. 114, p. 325-368, doi:10.1016/j.earscirev.2012.06.007.

324 Trettin, H., 1987, Pearya: A composite terrane with Caledonian affinities in northern

325 Ellesmere Island: Canadian Journal of Earth Sciences, v. 24, p. 224-245,

326 doi:10.1139/e87-025.

327 Trotter, J.A., Williams, I.S., Barnes, C.R., Lécuyer, C., and Nicoll, R.S., 2008, Did

328 cooling oceans trigger Ordovician biodiversification? Evidence from conodont

329 thermometry: Science, v. 321, p. 550-554, doi:10.1126/science.1155814.

330 Van der Voo, R., Johnson, R.J., van der Pluijm, B.A., and Knutson, L.C., 1991,

331 Paleogeography of some vestiges of Iapetus: Paleomagnetism of the Ordovician

332 Robert's Arm, Summerford, and Chanceport groups, central Newfoundland:

333 Geological Society of America Bulletin, v. 103, p. 1564-1575, doi:10.1130/0016-

$334 \quad 7606(1991) 103<1564:$ POSVOI $>2.3 . C O ; 2$.

335 van Staal, C., and Barr, S., 2012, Lithospheric architecture and tectonic evolution of the

336 Canadian Appalachians and associated Atlantic margin, in Percival, J.A., et al., eds.,

337 Tectonic styles in Canada: The Lithoprobe perspective: Geological Association of

$338 \quad$ Canada Special Paper 49, p. 41-96.

Page 15 of 17 
Publisher: GSA

Journal: GEOL: Geology

DOI:10.1130/G38985.1

339 Veizer, J., and Prokoph, A., 2015, Temperatures and oxygen isotopic composition of

$340 \quad$ Phanerozoic oceans: Earth-Science Reviews, v. 146, p. 92-104,

341 doi:10.1016/j.earscirev.2015.03.008.

342 Young, S.A., Saltzman, M.R., Foland, K.A., Linder, J.S., and Kump, L., 2009, A major

343 drop in seawater ${ }^{87} \mathrm{Sr} /{ }^{86} \mathrm{Sr}$ during the middle Ordovician (Darriwilian): Links to

344 volcanism and climate?: Geology, v. 37, p. 951-954, doi:10.1130/G30152A.1.

\section{FIGURE CAPTIONS}

346 Figure 1. Paleogeographic reconstruction ca. $465 \mathrm{Ma}$, after the arrival of the leading edge

347 of the Taconic arc system in the tropics along with the paleolatitude from allochthonous

348 volcanic rocks shown with $95 \%$ uncertainty. The reconstructed positions of these

349 paleomagnetic localities are shown on the classic position of Laurentia (as in Torsvik and

350 Cocks, 2017) and the new position proposed herein. While Laurentia most have been

351 north of these volcanics, in the classic reconstruction their positions

352 are south of the paleolatitudinal constraints

353 rather than equatorward, as in the revised position. The positions of other continental

354 blocks are as in Torsvik and Cocks (2017), other than Carolinia, which is modified to be

355 traveling in unison with Ganderia.

357 Figure 2. Paleomagnetic and geochemical data from 500 to 400 Ma. A: Paleolatitude

358 constraints for Laurentia, Taconic arc terranes (Popelogan-Victoria, Bronson Hill,

359 Annieopsquotch, and Notre Dame), and the peri-Gondwana Ganderia and Avalonia

360 terranes. Laurentia paleolatitudes are calculated for two localities on the margin from

361 paleomagnetic poles with the implied position of New York (NY) shown for the classic 
Publisher: GSA

Journal: GEOL: Geology

DOI: $10.1130 / \mathrm{G} 38985.1$

362 and new models. B: Strontium isotope data from conodont apatite and brachiopod calcite

363 with a locally weighted scatterplot smoothing (LOWESS) regression curve to the data of

364 Saltzman et al. (2014). C: Neodymium isotope data from fine-grained siliciclastic rocks

365 on the Appalachian margin of Laurentia with a LOWESS curve for distal margin data. D:

366 Oxygen isotope data from conodont apatite and brachiopod calcite with a LOWESS

367 curve for the brachiopod data. VPDB — Vienna Peedee belemnite; VSMOW—Vienna

368 standard mean ocean water. E: Orogenic phases wherein Taconic 2 spans the collision of

369 the leading edge of the arc system with promontories of the Laurentian margin. The peak

370 of Taconic 2 coincides with arc exhumation in the tropics and weathering of ophiolite and

371 arc detritus into Laurentian foreland basins. Late Ordovician arc accretion composes

372 Taconic 3. Data sources are provided in the Data Repository (see footnote 1).

373

$374{ }^{1}$ GSA Data Repository item 2017238, details of the paleomagnetic and

375 chemostratigraphic data compilations, is available online at

376 http://www.geosociety.org/datarepository/2017/ or on request from

377 editing@geosociety.org. 


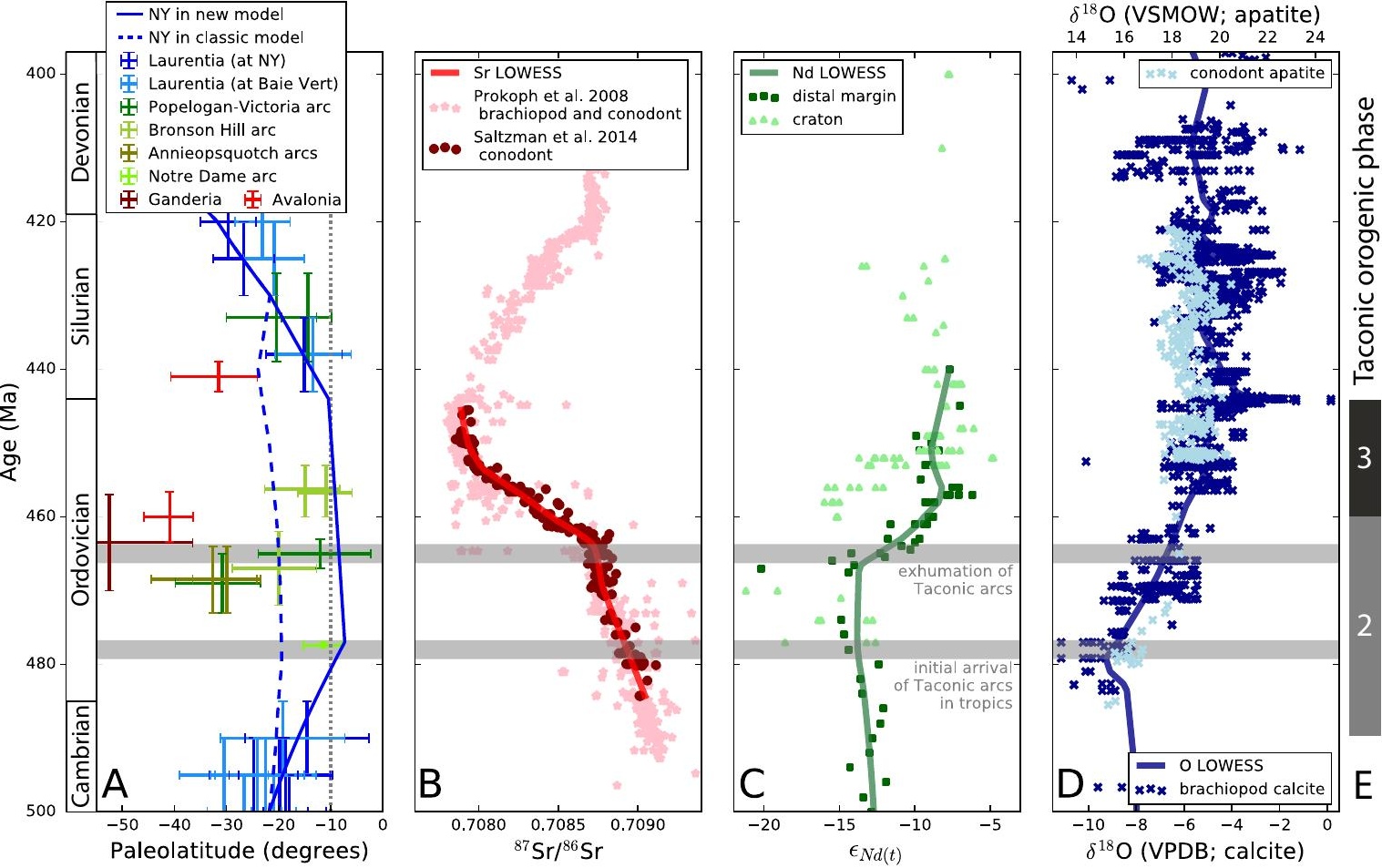

